\title{
Mechanical Properties of Mortars Containing Waste Glass Powder
}

\author{
Elżbieta Horszczaruk ${ }^{1 *}$, Piotr Brzozowski \\ ${ }^{1}$ Department of Concrete Stuctures and Concrete Technology, Faculty of Civil Engineering and Architecture, West Pomeranian \\ University of Technology Szczecin, al. Piastów 50, 70-311 Szczecin, Poland \\ * Corresponding author, e-mail: elzbieta.horszczaruk@zut.edu.pl
}

Received: 25 June 2018, Accepted: 06 February 2019, Published online: 01 April 2019

\begin{abstract}
The utilization of solid waste materials or industrial waste as partial substitution of cement is growing in construction industry all around world. Less cement consumption causes consequently reduction in $\mathrm{CO} 2$ emission into the atmosphere and reduction in energy consumption. This paper examines the possibility of using finely ground waste glass as a partial replacement for cement and as a sealing admixture. Glass powder used in the research was prepared from the glass waste obtained from a local recycling company. Glass cullet made of brown glass, which after rinsing to remove sugars and other impurities, was dried and ground to a fraction below $125 \mu \mathrm{m}$. This paper is the revised version of the paper that has been published in the Proceedings of the Creative Construction Conference 2018 (Horszczaruk and Brzozowski, 2018).
\end{abstract}

\section{Keywords}

cement composites, waste glass powder, recycling, mechanical properties

\section{Introduction}

Glass, being an inert material, is commonly used for the production of packaging. Glass recycling in Europe is among the most advanced in the world. In some European countries, nearly $85 \%$ of glass packaging, especially bottles and jars, are made from recyclate. Glass that is made of sand, a commonly occurring raw material, can be melted many times without losing its value. Unfortunately, these advantageous features of glass packaging, especially in the terms of used packaging and glass cullet formed from them, are not rationally used in Poland. Industrial cullet associated with the technological process of glassware production in Poland is about $28 \%$ of the total amount of cullet possible to re-use (Kuśnierz, 2010). Cullet, which comes from car windows, from "safe" glass or from CRT glass is a particularly serious problem. These types of cullet are not used by glassworks and other ways of their utilization have to be found.

When assessing the possibility of using waste glass in the construction industry in terms of its impact on the natural environment, some benefits can be observed. Primarily the reduction of the storage of waste material can be mentioned. There is also the possibility of the use of the waste glass as a substitute of materials derived from natural resources. The waste glass used for concretes does not significantly affect the level of environmental impact of the obtained material. An exception may be glass cullet coming from CRT glass, containing significant amounts of heavy metals (Najduchowska et al., 2014).

Waste glass in the construction industry is used, for example, for the production of mats and insulation boards, grits for plaster, as an addition to ceramic masses, mortars and cement concretes (Ganjian et al., 2015; Isa, 2008; Liu, 2011; Rashad, 2014; Sahmenko et al., 2014; Sikora et al., 2015).

In the case of the use of waste glass in cement composites, the replacement of natural fine aggregate with fine ground glass cullet has proved to be the most effective so far (Byars et al., 2004; Park et al., 2004). The use of waste glass as coarse aggregate in concrete does not have a significant impact on the workability. However, it significantly influences its mechanical properties. According to tests described in the papers (Keerio et al., 2017; Topçu and Canbaz, 2004) compressive strength decreases in proportion to the increase in the amount of glass cullet in concrete.

Research (Sérifou et al., 2013) has shown that the use of the waste glass as a coarse aggregate may decrease the mechanical properties of cementitious composites due to 
the cracking of the larger grains. The use of waste glass as a substitute for fine aggregate in mortar and concrete results in reduced workability of the composite with the incense of the content of waste glass (Schwarz et al., 2008).

A significant increase in mechanical properties and durability of concrete was observed when very finely grounded glass was used as a cement substitute (Carsana et al., 2014; Idir et al., 2010; Matos and Sousa-Coutinho, 2012; Shi et al., 2005). Moreover, another research (Shao et al., 2000) showed that the smaller size of glass particles leads to higher reactivity with lime, which results in higher compressive strength of concrete and smaller expansion related to the alkali-silica reaction.

The paper presents the results of cement mortar tests, in which the waste glass from brown glass was used. The waste glass was ground to a fraction with a maximum grain size $125 \mu \mathrm{m}$. The glass powder, prepared this way, was used in the tested mortars as a sealing admixture and a cement replacement.

Based on the interesting results of previous experiments (Horszczaruk and Brzozowski, 2018), the study was extended to investigate the properties of mortars after 56 days of hardening. What is more, pozzolanic effect of waste glass powder was determined.

\section{Materials and methods}

\subsection{Materials}

Cement mortar was made using Portland cement CEM I 42.5R (according to PN-EN 197-1), fine aggregate and tap water. The fine aggregate was CEN standard quartz sand with a grain size compliant with the requirements of PN-EN 196-1. Glass powder was prepared from the glass waste obtained from a local recycling company. Prior incorporation to cement mortars, the waste glass was washed in water (in order to remove contaminants), dried and ground to obtain a glass powder with a maximum grain size $125 \mu \mathrm{m}$. The gradation curve was conforming to PN-EN 196-1. Table 1 presents the chemical composition of waste glass used. Fig. 1 shows a photography of the waste glass after milling process.

\subsection{Mixture composition and mortar preparation}

Cement mortars with the constant aggregate to cement to water ratio $3: 1: 0.5$ were prepared according to the PN-EN 196-1. Two groups of cement mortars were prepared. The first group of cement mortars was designed as $R$ (reference mortar). Digits 0, 3 and 5 next to the name of the mortar indicated the percentage content of the glass

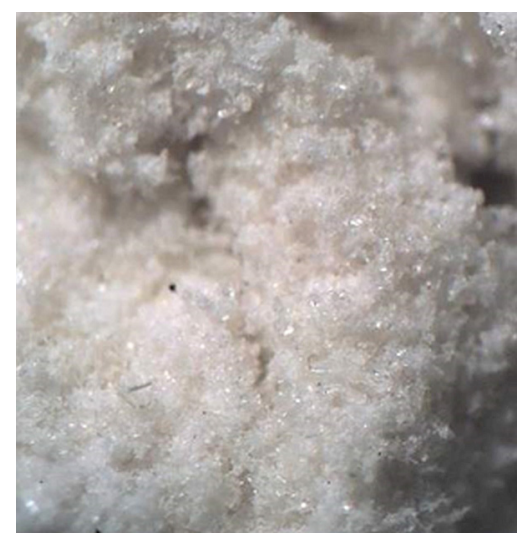

Fig. 1 Photography of the waste glass after milling process $(25 \times)$

Table 1 Chemical composition of the waste glass

\begin{tabular}{lccccc}
\hline Component & $\mathrm{SiO}_{2}$ & $\mathrm{M}_{2} \mathrm{O}_{3}$ & $\mathrm{Fe}_{2} \mathrm{O}_{3}$ & $\mathrm{CaO}$ & $\mathrm{MgO}$ \\
\hline Content [\%] & 71.51 & 1.67 & 1.66 & 10.24 & 1.64 \\
Component & $\mathrm{SO}_{3}$ & $\mathrm{~K}_{2} \mathrm{O}$ & $\mathrm{Na}_{2} \mathrm{O}$ & $\mathrm{P} 2 \mathrm{O} 5$ & $\mathrm{TiO}_{2}$ \\
Content [\%] & 0.07 & 0.55 & 12.35 & 0.02 & 0.21 \\
Component & $\mathrm{Mn}_{2} \mathrm{O}_{3}$ & $\mathrm{BaO}$ & $\mathrm{SrO}$ & & \\
Content [\%] & 0.05 & 0.56 & 0.02 & & \\
\hline
\end{tabular}

powder, in relation to the cement mass. The second group of mortars were marked as $M 10$ and $M 20$. In these mortars $10 \%$ and $20 \%$ of the mass of the cement was replaced with glass powder, respectively. The composition of the tested mortars is presented in Table 2. After demoulding, the mortars were stored at $20^{\circ} \mathrm{C} \pm 2{ }^{\circ} \mathrm{C}$ and relative humidity $R H>95 \%$ for 28 days.

\subsection{Test methods}

The consistency of cement mortars was tested by a flow table according to PN-EN 1015-3. Flexural strength and compressive strength of mortars were determined in accordance with PN-EN 197-1 after 28 and 56 days of curing. Six prisms in size of $40 \times 40 \times 160 \mathrm{~mm}$ were prepared for each type of mortar for the determination of strength. Water absorption test, by soaking, was conducted in accordance with PN-B-04500:1985. For this test 3 prisms of each type of mortar in size of $40 \times 40 \times 160 \mathrm{~mm}$ were used.

\section{Results and discussion}

Table 2 and Fig. 2 present the consistency of fresh cement mortars determined by the flow table method. The addition of the glass powder had a slight effect on the deterioration of the consistency of $R 3$ and $R 5$ mortars, and both mortars maintained their workability. The use of glass powder as a cement replacement did not significantly affect the consistency of the mortars, and in the case of M20 mortar, the 
Table 2 Mixture compositions and consistency of fresh cement mortars designation

\begin{tabular}{lccccc}
\hline Sample & $R 0$ & $R 3$ & $R 5$ & $M 10$ & $M 20$ \\
\hline Cement $\left[\mathrm{kg} / \mathrm{m}^{3}\right]$ & 519 & 519 & 519 & 467 & 415 \\
Water $\left[\mathrm{kg} / \mathrm{m}^{3}\right]$ & 257 & 257 & 257 & 257 & 239 \\
Sand $\left[\mathrm{kg} / \mathrm{m}^{3}\right]$ & 1546 & 1546 & 1546 & 1546 & 1546 \\
Glass powder $\left[\mathrm{kg} / \mathrm{m}^{3}\right]$ & - & 15.5 & 26.0 & 52.0 & 104.0 \\
$\begin{array}{l}\text { Consistency, mean } \\
\text { diameter }[\mathrm{mm}]\end{array}$ & 165 & 150 & 147 & 155 & 163 \\
\hline
\end{tabular}

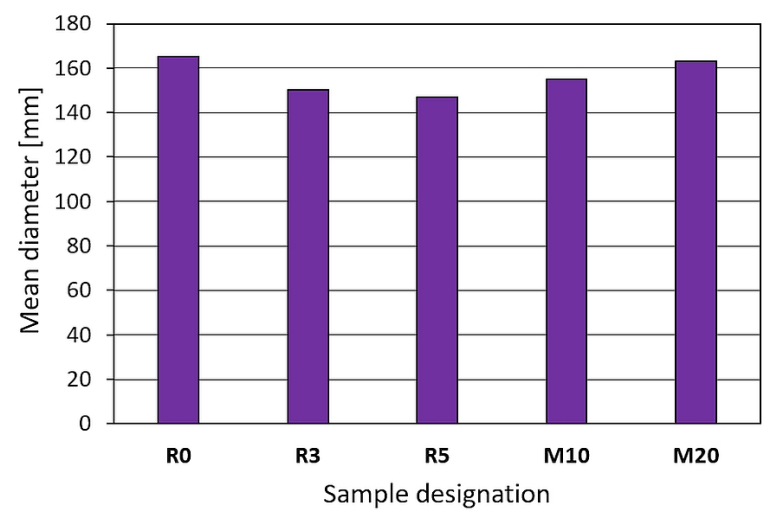

Fig. 2 Consistency of fresh cement mortar

consistency obtained was similar to the consistency of the reference mortar $R 0$.

Fig. 3 presents the results of the mass absorption testing of mortar samples. Addition of the glass powder slightly improves the absorption resistance of the tested mortars. However, for the M20 mortar, water absorption similar to the reference mortar $R 0$ was obtained.

Fig. 4 presents flexural strength after 28 and 56 days of curing. The use of waste glass did not significantly affect the flexural strength of the tested mortars. For $R 5$ mortar, a slight increase in flexural strength by $1.5 \%$ was observed. This may be related to the sealing of the composite structure by glass flour. The use of waste glass as a cement replacement resulted in a reduction in the flexural strength of mortars by about $9 \%$ and $14 \%$ for mortar $M 10$ and $M 20$ respectively.

After 28 days, the compressive strength of the tested mortars decreased with the increase of the content of the waste glass in the mortar (Fig. 5). The use of the glass powder as an admixture caused a slight decrease in strength by $3.7 \%$ and $2.5 \%$. However, for mortars $M 10$ and $M 20$, the decrease of compressive strength was $14 \%$ and $20 \%$, respectively. The low grinding degree of the glass powder could be the reason for its negative effect on the compressive strength of the tested mortars. As shown by research

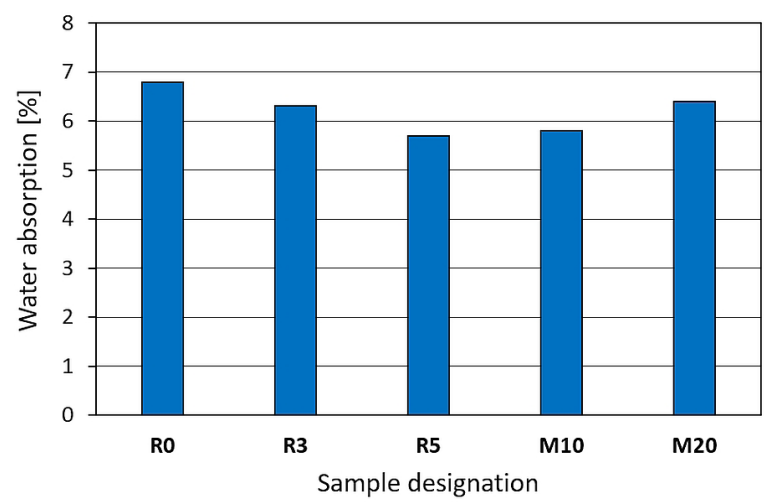

Fig. 3 Water absorption of cement mortars

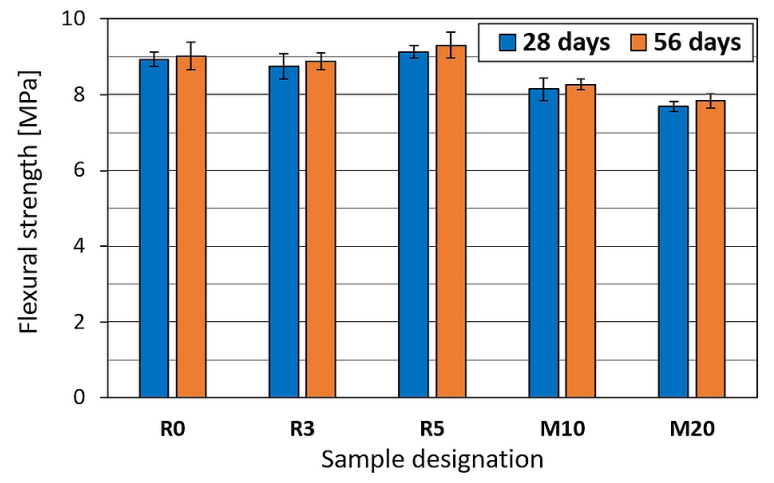

Fig. 4 Flexural strength of cement mortars after 28 and 56 days of curing

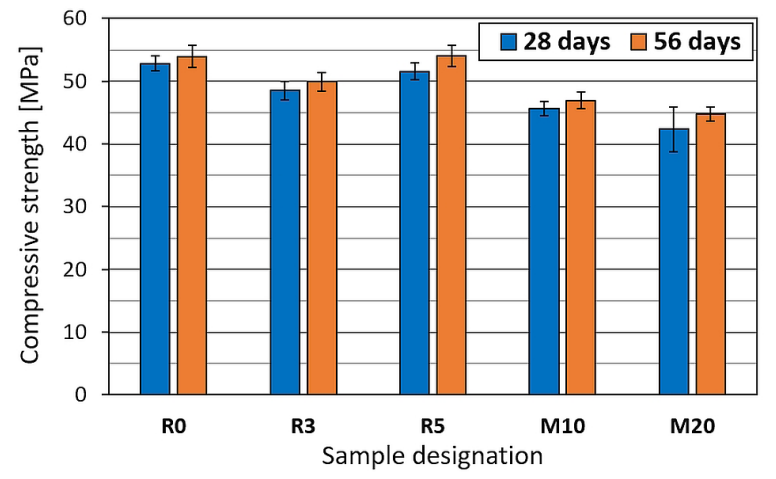

Fig. 5 Compressive strength of cement mortars after 28 and 56 days of curing

(Matos and Sousa-Coutinho, 2012), when using $20 \%$ glass powder (as the cement substitute) of fractions up to $40 \mu \mathrm{m}$, the mortars obtained compressive strength similar to the reference mortars. The use of the glass powder of fractions $80-100 \mu \mathrm{m}$ resulted in a compressive strength drop by $20-23 \%$, regardless of the color of the glass used.

After 56 days of curing mortars containing waste glass performed higher increments of their compressive strength compared to mortar $R 0$. The biggest increment was observed for mortars $R 5$ and $M 20$. 
The pozzolanic effect of waste glass powder was assessed with the Activity Index (AI) (Fig. 6) which is the ratio between compressive strength of mortar containing waste glass powder and strength of equivalent control mortar $(R 0)$ at the same age.

For all mortars containing waste glass the increasement of $A I$ in time was observed. Moreover, after 56 days of curing for $R 5$ mortar Activity Index greater than $100 \%$ was achieved.

The best properties were obtained for $R 5$ mortar, with $5 \%$ content of the glass powder. It had good workability, high flexural strength and slightly lower compressive strength in comparison to the reference mortar $R 0$.

\section{Summary}

The paper presents the experimental results of investigations of the cement mortars modified with a variable amount of the glass powder of fractions up to $125 \mu \mathrm{m}$. Based on the obtained results, it was assessed that the idea of using the glass powder derived from the waste glass for the modification of the composition of cement mortars is promising. The addition of the glass powder in the amount of $5 \%$ of the cement mass resulted in the structure sealing, smaller water absorption and the improvement of the workability of fresh mortar while maintaining its mechanical properties after 28 and 56 days of curing.

\section{References}

Byars, E. A., Morales-Hernandez, B., Zhu, H. Y. (2004) "Waste glass as concrete aggregate and pozzolan Laboratory and industrial projects", Concrete, 38(1), pp. 41-44.

Carsana, M., Frassoni, M,, Bertolini, L. (2014) "Comparison of ground waste glass with other supplementary cementitious materials", Cement and Concrete Composites, 45, pp. 39-45. https://doi.org/10.1016/j.cemconcomp.2013.09.005

Ganjian, E., Jalull, G., Sadeghi-Pouya, H. (2015) "Using waste materials and by-products to produce concrete paving blocks", Construction and Building Materials, 77, pp. 270-275. https://oi.org/10.1016/j.conbuildmat.2014.12.048

Horszczaruk, E., Brzozowski, P. (2018) "A study of the possibility of using ground waste glass as a replacement for cement in cement composites", In: Creative Construction Conference 2018, CCC 2018, Ljubljana, Slovenia, pp. 115-120. https://doi.org/10.3311/CCC2018-016

Idir, R., Cyr, M., Tagnit-Hamou, A. (2010) "Use of fine glass as ASR inhibitor in glass aggregate mortars", Construction and Building Materials, 24(7), pp. 1309-1312. https://doi.org/10.1016/j.conbuildmat.2009.12.030

Isa, H. (2008) "The need for waste management in the glass industries: A review", Scientific Research and Essay, 3(7), pp. 276-279.

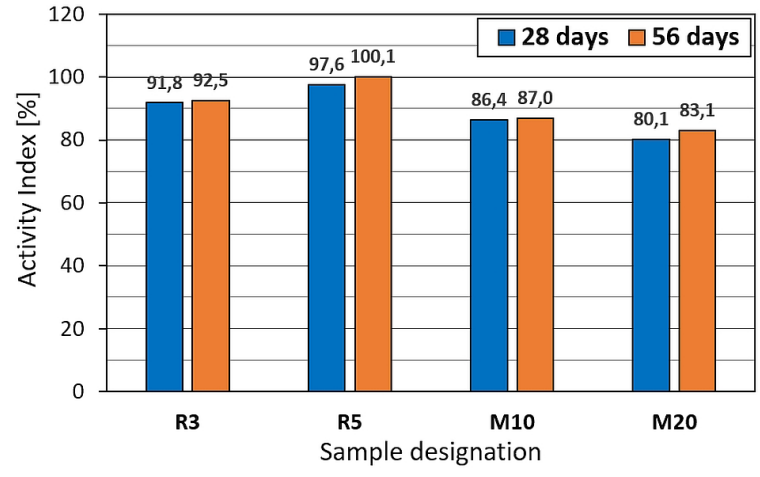

Fig. 6 Activity Index at 28 and 56 days of curing

The use of the glass powder as a cement replacement in the amount of $10-20 \%$ does not reduce mortar workability, however, it causes deterioration of the mechanical properties of the mortar. The improvement of mechanical properties can be obtained by using glass powder with a smaller diameter of the maximum fraction, which is confirmed by research (Matos and Sousa-Coutinho, 2012).

\section{Acknowledgement}

This research was funded by the National Centre for Research and Development within SEFIRCAOM 2/ KONNECT/2016 (KONNECT Joint Call).

Keerio, M. A., Khoso, S., Khan, J. S., Ansari, A. A., Bhatti, N. K. (2017) "The effect of Waste Glass as Partial Replacement of cement on Properties of Concrete", Engineering Science and Technology International Research Journal, 1(1), pp. 59-63.

Kuśnierz, A. (2010) "Recykling szkła" (Glass recycling), Scientific Works of Institute of Ceramics and Building Materials, 3(6), pp. 22-33. (in Polish)

Liu, M. (2011) "Incorporating ground glass in self-compacting concrete", Construction and Building Materials, 25(2), pp. 919-925. https://doi.org/10.1016/j.conbuildmat.2010.06.092

Matos, A. M., Sousa-Coutinho, J. (2012) "Durability of mortar using waste glass powder as cement replacement", Construction and Building Materials, 36, pp. 205-215. https://doi.org/10.1016/j.conbuildmat.2012.04.027

Najduchowska, M., Różycka, K., Rolka, G. (2014) "Ocena możliwości wykorzystania stłuczki szklanej w przemyśle budowlanym w aspekcie jej wpływu na środowisko naturalne" (Assessment of the glass cullet application in building industry in terms of its impacts on the environment), Scientific Works of Institute of Ceramics and Building Materials, 7(17), pp. 46-56. (in Polish)

Park, S. B., Lee, B. C., Kim, J. H. (2004) "Studies on mechanical properties of concrete containing waste glass aggregate", Cement and Concrete Research, 34(12), pp. 2181-2189. https://doi.org/10.1016/j.cemconres.2004.02.006 
Rashad, A. M. (2014) "Recycled waste glass as fine aggregate replacement in cementitious materials based on Portland cement", Construction and Building Materials, 72, pp. 340-357. https://doi.org/10.1016/j.conbuildmat.2014.08.092

Sahmenko, G., Toropovs, N., Sutinis, M., Justs, J. (2014) "Properties of High Performance Concrete Containing Waste Glass MicroFiller", Key Engineering Materials, 604, pp. 161-164. https://doi.org/10.4028/www.scientific.net/KEM.604.161

Sérifou, M., Sbartaï, Z. M., Yotte, S., Boffoué, M. O., Emeruwa, E., Bos, F. (2013) "A Study of Concrete Made with Fine and Coarse Aggregates Recycled from Fresh Concrete Waste", Journal of Construction Engineering, 2013, article ID: 317182. https://doi.org/10.1155/2013/317182

Schwarz, N., Cam, H., Neithalath, N. (2008) "Influence of a fine glass powder on the durability characteristics of concrete and its comparison to fly ash", Cement and Concrete Composites, 30(6), pp. 486-496.

https://doi.org/10.1016/j.cemconcomp.2008.02.001
Shi, C., Wu, Y., Riefler, C., Wang, H. (2005) "Characteristics and pozzolanic reactivity of glass powders", Cement and Concrete Research, 35(5), pp. 987-993.

https://doi.org/10.1016/j.cemconres.2004.05.015

Shao, Y., Lefort, T., Moras, S., Rodriguez, D. (2000) "Studies on concrete containing ground waste glass", Cement and Concrete Research, 30(1), pp. 91-100. https://doi.org/10.1016/S0008-8846(99)00213-6

Sikora, P., Horszczaruk, E., Rucinska, T. (2015) "The Effect of Nanosilica and Titanium Dioxide on the Mechanical and Self-Cleaning Properties of Waste-Glass Cement Mortar", Procedia Engineering, 108, pp. 146-153. https://doi.org/10.1016/j.proeng.2015.06.130

Topçu, İ. B., Canbaz, M. (2004) "Properties of concrete containing waste glass", Cement and Concrete Research, 34(2), pp. 267-274. https://doi.org/10.1016/j.cemconres.2003.07.003 